\title{
弁ばねの疲労寿命に及ぼす表面疵の影響*
}

\author{
寺下 勝**，小林武夫**，礒野裕司** \\ 川口康信 $* * *$, 佐藤仁資 $* *$, 蔵本廣志***
}

\section{Influence of Surface Flaws on Fatigue Life of Valve Springs}

\author{
Masaru TERASHITA, Takeo KOBAYASHI, Yuji ISONO, \\ Yasunobu KAWAGUCHI, Hitoshi SATOH and Hiroshi KURAMOTO
}

\begin{abstract}
Surface flaws on valve springs in automobile engines are one of the crucial factors which affect the fatigue life of valve springs together with harmful non-metallic inclusions and surface decarburization. Through the fatigue tests of high tensile strength springs and nitrided springs with artificial longitudinal flaws, the influence of surface flaws on fatigue lives were investigated.

Fatigue lives of both springs lowered as the depth of flaws increased, however, in this experiment, when flaw depth was not deeper than $0.05 \mathrm{~mm}$, no lowering of each fatigue strength was recognized. It was considered as this reason, that the large compressive residual stress of the surface layer effectively suppressed propagation of fatigue crack.
\end{abstract}

Key Words : Surface flaw, Fatigue life, Valve spring, Nitrided spring, Residual stress

\section{1. 緒 言}

近年の自動車の低燃費化の動きに伴い，エンジン用弁ば ねに扔いても高応力設計が指向されている。そのため負荷 応力の増加に対応できる優れた疲労強度を有する弁ばねの 要望が強い。現在日本では弁ばね用として, 引張強さ $1900 \mathrm{~N} / \mathrm{mm}^{2}$ 級のSi-Cr鋼オイルテンパー線（JIS SWOSC-V, SAE9254 相当）が多く使用されているが，この要望に対応 するために SWOSC-Vより引張強さを高めた高強度オイル テンパー線が開発され ${ }^{1)}, 2$ 段ショットピーニングなどのシ ヨットピーニング技術の改善 ${ }^{1)}$ と組み合わされて数年前か ら害用化されている。また窒化処理は表層硬さを増加し, 表面に圧縮残留応力を付与するため疲労強度の向上に有効 であり，弁ばねへの適用も普及しつつある ${ }^{2), 3)}$

弁ばねに扔いて，表面疪は非金属介在物，表面脱炭などの 欠陥と共に疲労寿命に影響を及ほす寸重要な要因である。しかし， 従来の弁ばねに比べて表層硬さが高いこれら弁ばねの疲労特性 に及ぼす表面疪の影響はこれまであまり明確にされていない。

そこで，高強度弁ばね用鋼を用いて人工疪（縦疪）を付 与したオイルテンパー線を試作し, 高強度弁ばね及び窒化 弁ばねの疲労寿命に及ぼす表面疪の影響を検討した。

\section{1 供試材の化学成分}

\section{2. 実験方法}

供試材として，JIS SWOSC-V の引張強さを上回る高強度
弁ばね用鋼として開発・実用化されている鋼を用いた。そ の化学成分を Table 1 に示すが, SWOSC-Vに比べて拉も にC 含有量を増加することによって引張強さの向上を図っ ている。また, $\mathrm{V}, \mathrm{Ni}$ の添加により引張強さの増加に伴う 勒延性の低下を防いでいる。これらにより通常の SWOSC-V と同等の延性を保持し, 約 $150 \mathrm{~N} / \mathrm{mm}^{2}$ 高い引張 強さを有するオイルテンパー線の製造が可能である。参考 として Fig. 1 に供試鋼の焼戻し温度と機械的性質の関倸を SWOSC-V 鋼と比較して示す。

\section{2 供試材の製造工程}

供試材ばねの製造工程を Fig. 2 に示す。

ここで, 疪入り線材 (縦疪)を得る方法として, Fig. 3 に 示すように表面手入れを行った $155 \mathrm{~mm}$ 角の鋼片表面に片 端より長さ方向に次第に浅くなる人工溝を切削加工し, 熱 間圧延により線径 $\phi 7.0 \mathrm{~mm}$ の線材を製作した。鋼片での人 工洅深さは, 素線径 $\phi 3.2 \mathrm{~mm}$ のばねで疪深さが $0 \sim 0.3 \mathrm{~mm}$ 程度になるように設定した。また，ばねで最大応力がかか るばね内側にいずれかの疵がくることを狙って鋼片の四面 に人工溝を加工した。

線材圧延以降は Fig. 2 に示すように通常の製造工程と

Table 1 Chemical composition of steel tested (mass\%)

\begin{tabular}{|c|c|c|c|c|c|c|}
\hline Grade & $\mathrm{C}$ & $\mathrm{Si}$ & $\mathrm{Mn}$ & $\mathrm{Ni}$ & $\mathrm{Cr}$ & $\mathrm{V}$ \\
\hline Steel A & 0.60 & 1.48 & 0.70 & 0.31 & 0.87 & 0.06 \\
\hline
\end{tabular}

原稿受付日 1994 年 9 月26日

* ばね技術研究会, 1993年度秋季講演会及び Wire Association International, 1994年 64th Annual Convention にて発表

** サンコール (株) (Suncall, Corporation)

*** (株) 神戸製鋼所 (Kobe Steel, Ltd.) 


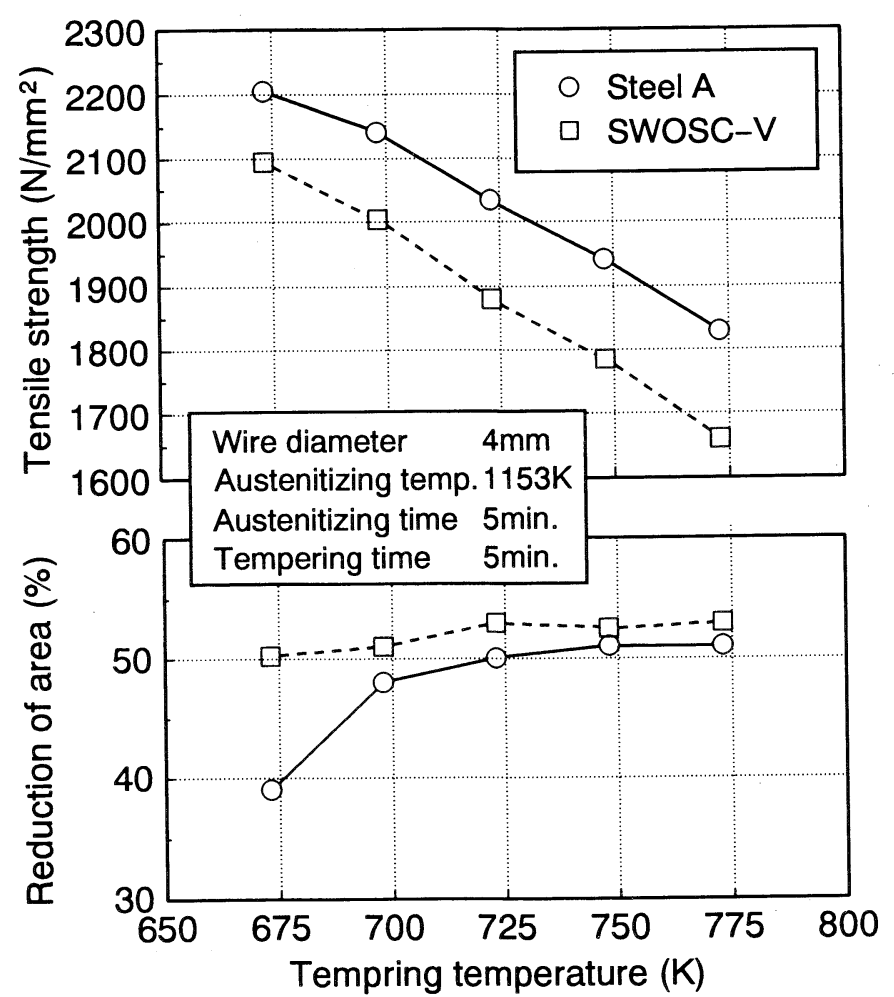

Fig. 1 Relationship between tempering temperature and mechanical properties

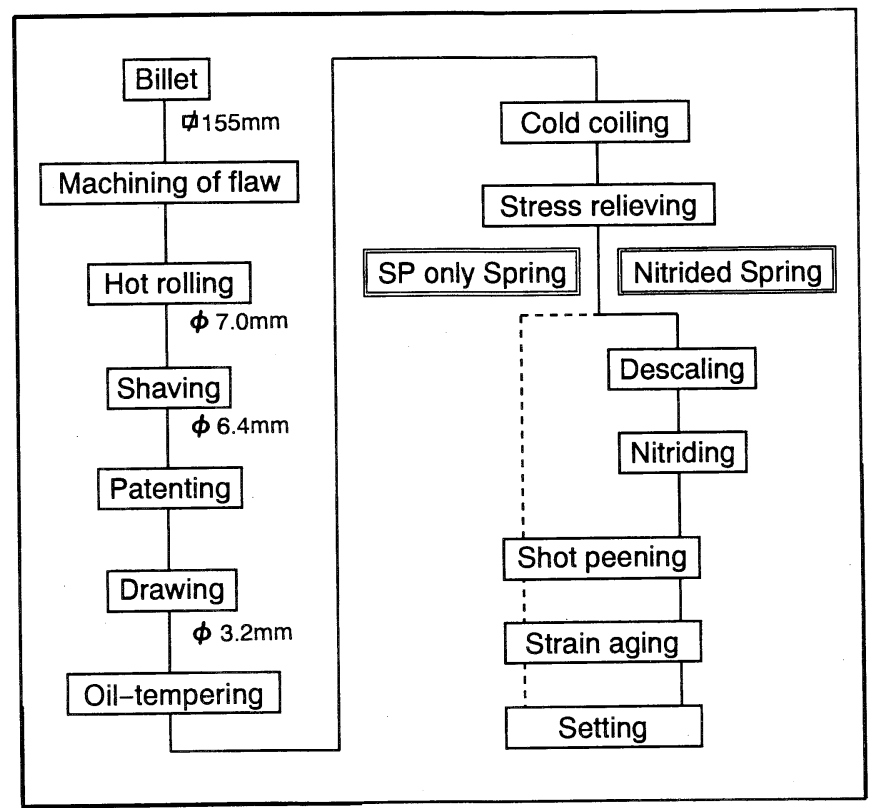

Fig. 2 Manufacturing process of springs tested

Table 2 Mechanical properties of oil-temperd wire used for experiment

\begin{tabular}{|c|c|c|c|c|}
\hline diameter & $\begin{array}{c}0.2 \% \text { Yield } \\
\text { strength } \\
(\mathrm{mm})\end{array}$ & $\begin{array}{c}\text { Tensile } \\
\text { strength } \\
\left(\mathrm{N} / \mathrm{mm}^{2}\right)\end{array}$ & $\begin{array}{c}\text { Elongation } \\
\left(\mathrm{N} / \mathrm{mm}^{2}\right)\end{array}$ & $\begin{array}{c}\text { Reduction } \\
\text { of area } \\
(\%)\end{array}$ \\
\hline$\phi 3.2$ & 1800 & 2048 & 4.0 & 54 \\
\hline
\end{tabular}

同一である。Table 2 にオイルテンパー線の機械的性質 を示す。

ばね成形後の製造工程も Fig. 2 に示すが，窒化処理を施 さないばね（SPのみのばね：SP only Spring と表す）と窒
Table 3 Treatment conditions of spring

\begin{tabular}{|c|c|}
\hline Stress relieving & Temp. $673 \mathrm{~K}$, Time $20 \mathrm{~min}$ \\
\hline Nitriding & Temp. $703 \mathrm{~K}$, Time $180 \mathrm{~min}$ \\
\hline Shot-peening & $\begin{array}{ll}\text { Shot diameter } & \phi 0.6 \mathrm{~mm} \\
\text { Shot velocity } & 73 \mathrm{~m} / \mathrm{sec} \\
\text { Peening time } & 40 \mathrm{~min} \\
\end{array}$ \\
\hline Strain aging & Temp. $493 \mathrm{~K}$, Time $20 \mathrm{~min}$ \\
\hline Setting & Setting stress $1176 \mathrm{~N} / \mathrm{mm}^{2}$ \\
\hline
\end{tabular}

Table 4 Dimension of springs tested

\begin{tabular}{|l|l|}
\hline Wire diameter & $\phi 3.2 \mathrm{~mm}$ \\
\hline Mean coil diameter & $\phi 21.2 \mathrm{~mm}$ \\
\hline Total number of coils & 6.5 \\
\hline Active number of coils & 4.5 \\
\hline Free height & $50 \mathrm{~mm}$ \\
\hline
\end{tabular}

Dimensions of flaw at portion $A$

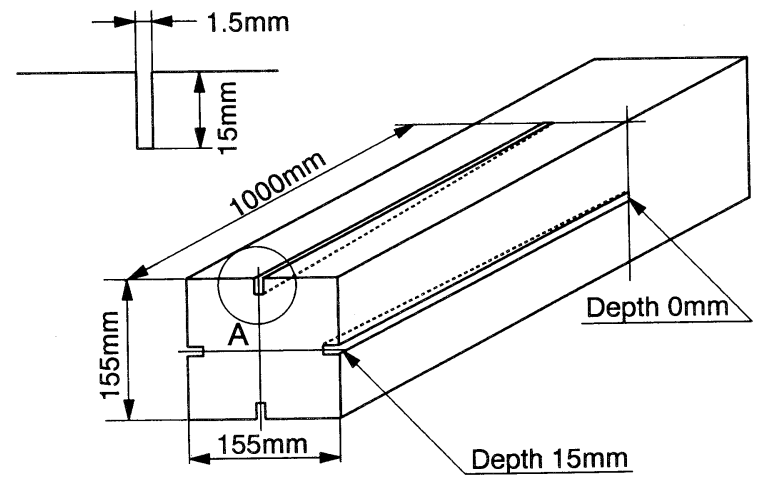

Fig. 3 Artificial flaws machined on billet

Table 5 Measurement conditions of residual stress

\begin{tabular}{|l|c|}
\hline X-ray used & CrK $_{\alpha}$ \\
\hline Filter & $\mathrm{V}$ \\
\hline Tube voltage & $40 \mathrm{kV}$ \\
\hline Tube current & $45 \mathrm{~mA}$ \\
\hline Window of slit & $\phi 0.5 \mathrm{~mm}$ \\
\hline Measurement direction & $\pi / 4 \mathrm{rad}$ against wire axis \\
\hline
\end{tabular}

化処理を施したばね（窒化ばね：Nitrided Spring と表す） を製作した。ばね製造条件を Table 3，供試ばねの諸元を Table 4 に示す。

\section{3 試験方法}

\subsection{1 疲労試験}

疲労試験に供するばねはコイリング時に断続的にサンプ リングし，疵深さ毎にグルーピングした。

各グループのばねを抜き取りでサンプリングし疵深さを 測定し，ばね疲労試験に供する時の目安にした。 


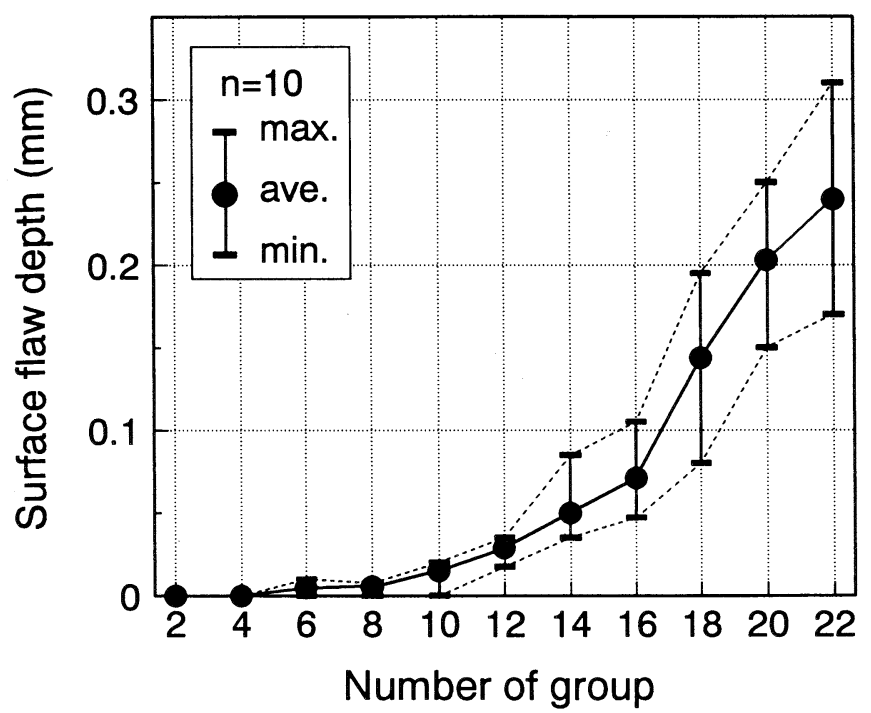

Fig. 4 Surface flaw depth for each spring group

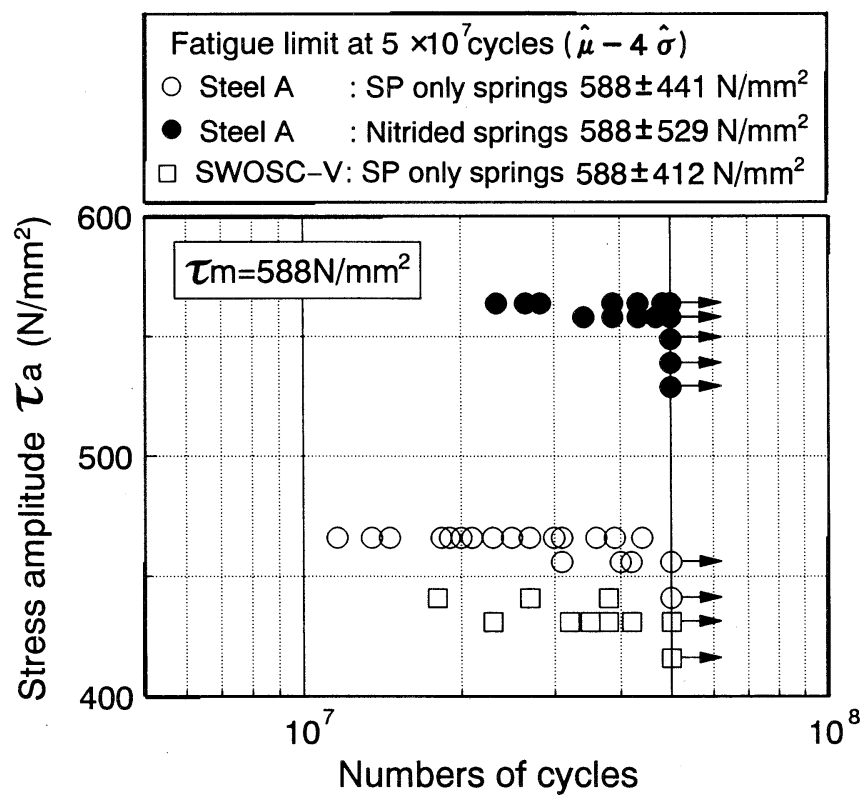

Fig. 5 Fatigue test results of springs without artifical surface flaw

ばねグループ毎の疵深さを Fig. 4 に示すが，グルーピン グ順に平均值で $0 \sim 0.25 \mathrm{~mm}$ と変化しており, 当初の計画 どおりの疵深さが得られた。

ばね疲労試験は油圧サーボ試験機を用いて変位制御で行 い，繰返し数は $5 \times 10^{7}$ 回で中止とした。まず人工疪のない $\mathrm{SP}$ みのばね及び窒化ばねについて応力振幅と疲労寿命の 関係を調心゙各々の疲労限を求めた。次に疪入りのばねにつ いて, 求めた疲労限応力で試験し疵深さと疲労寿命の関係 を求めた。

また，参考のために SWOSC-V の疵なし（SP のみ）のば ねについても疲労限を調査した。

\subsection{2 硬さ，残留応力分布}

一般的に，ばねにおける疲労破壊はばね内側表面を起点 とするため，ばね内側の表層部の硬さ及び残留応力分布を コード法 ${ }^{4)}$ 及び X 線応力測定装置を用いて測定した。残留
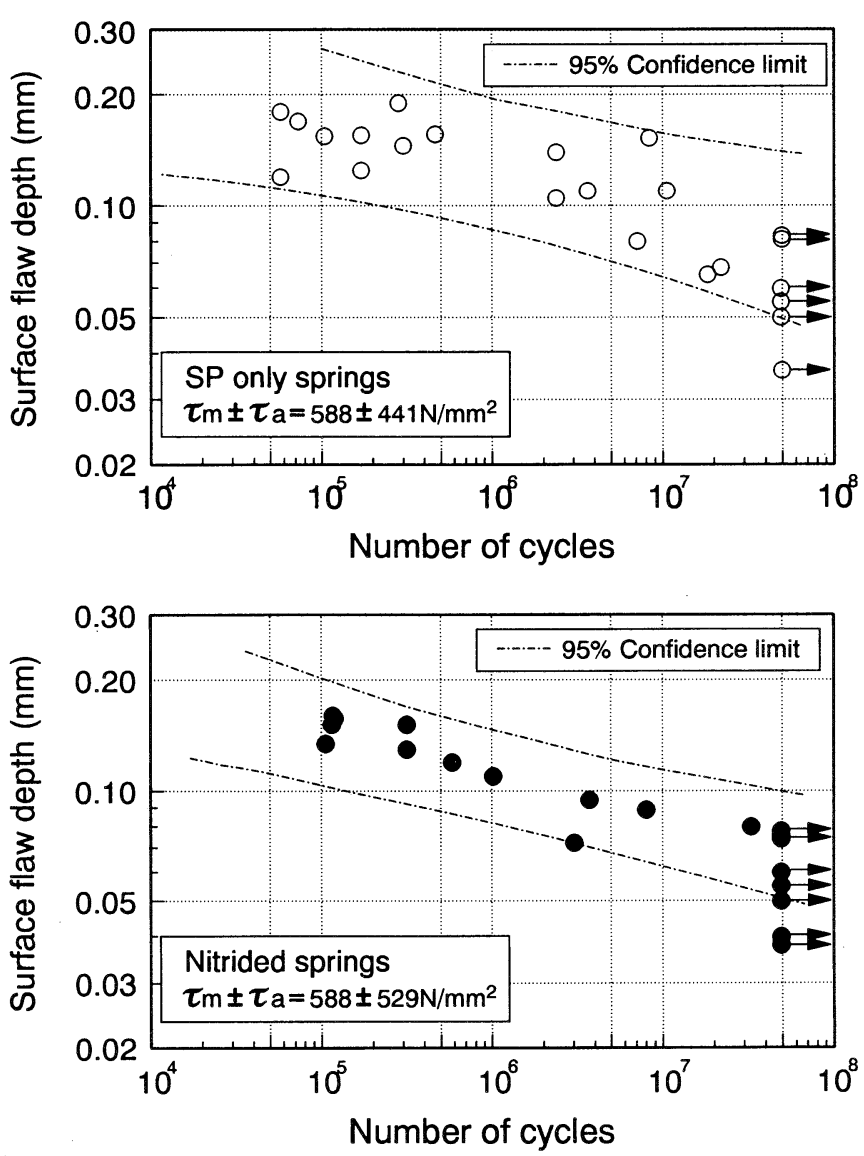

Fig. 6 Relationship between flaw depth at failure initiation point and fatigue life of shot-peened springs

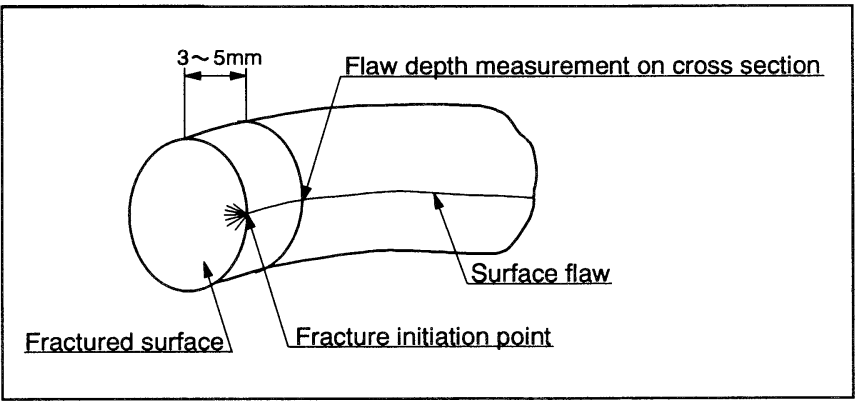

Fig. 7 Measurement of flaw depth of fracture initiation point

応力は化学研磨しながらばね内側を表面から深さ方向に測 定を行った。残留応力測定条件を Table 5 に示す。

\section{1 疲労試験}

\section{3. 実 験 結 果}

人工疪のない正常なばねの場合の応力振幅と疲労寿命の 関係を Fig. 5 に示す。疲労破壊の起点はすべてばね内側表面 部であった。供試鋼 $\mathrm{A}$ の疲労限応力振幅は SPのみのばねが 約 $440 \mathrm{~N} / \mathrm{mm}^{2}$, 窒化ばねが約 $530 \mathrm{~N} / \mathrm{mm}^{2}$ であり, SWOSC-V に比べてそれぞれ約 $30 \mathrm{~N} / \mathrm{mm}^{2}$ 及び約 $120 \mathrm{~N} / \mathrm{mm}^{2}$ 向上した。

疵入りばねの場合の疲労折損起点部の疵深さと疲労寿命 の関係を Fig. 6 に示す。疲労折損起点部の疵深さは, 疲労 破面からは正確に判定できなかったので, Fig. 7 に示すよ うに折損起点部から $3 \sim 5 \mathrm{~mm}$ 離れた位置の横断検鏡面に おける起点に対応する疵の深さを採用した。また， $5 \times 10^{7}$ 


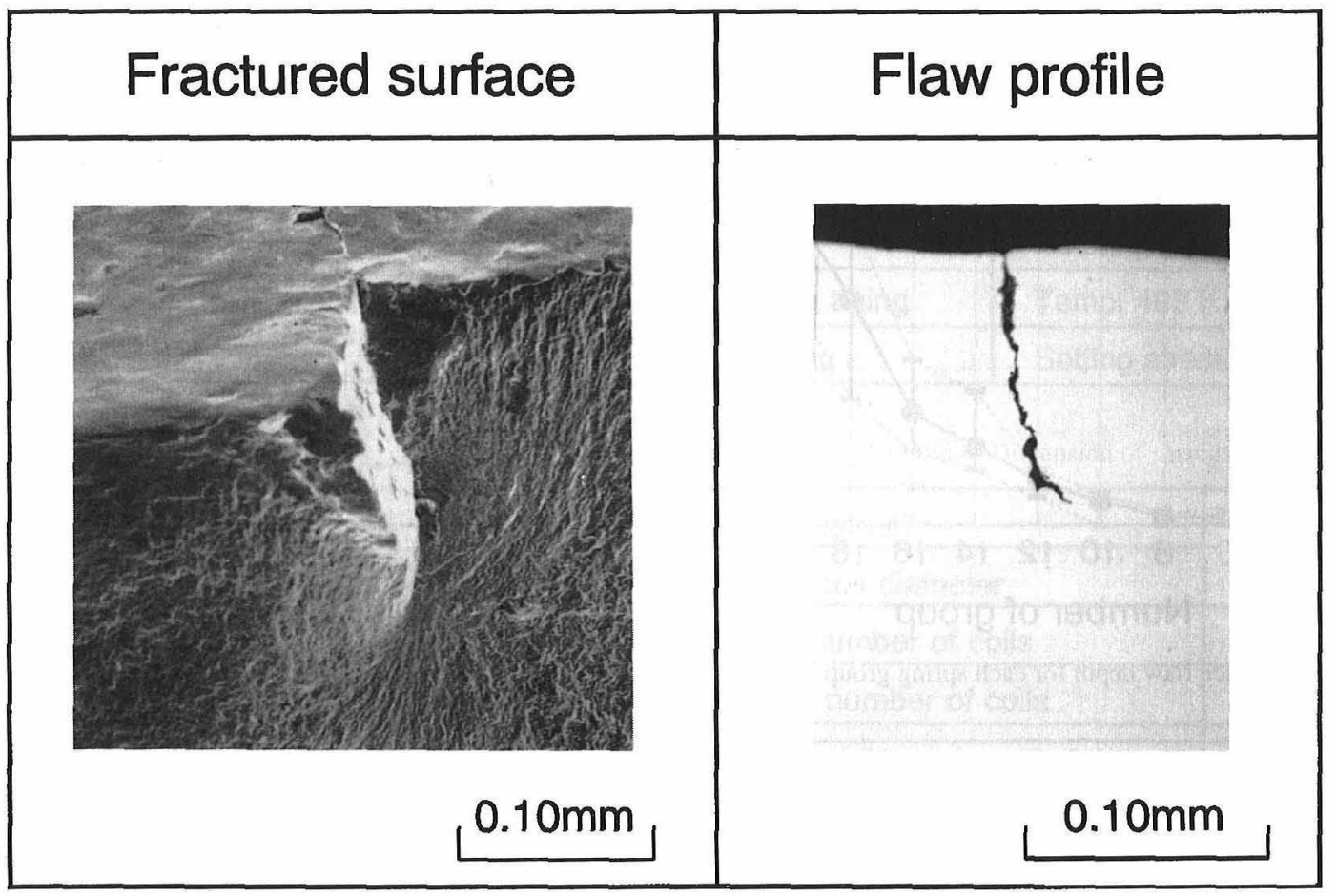

Fig. 8 Typical examples of fractured surface and flaw profile of microscopic cross section

回で折損しなかったばねについては端から 1.5 巻目の断面 のばね内側に位置する疪の深さを採用した。折損破面及び 横断検鏡面の疪形状の代表例を Fig. 8 に示す。

Fig. 6 に示すようにSP のみ及び窒化ばねともに，疪深さ が深くなるにつれて疲労寿命は低下していった。しかし，両 者とも疵深さが $0.05 \mathrm{~mm}$ 程度以下の場合では，繰返し数 $5 \times$ $10^{7}$ 回で未折損であり疲労強度の低下は認められなかった。

\section{2 硬さ分布}

Fig. 9 にばね表層硬さ分布の測定結果を示す。供試鋼 A の $\mathrm{SP}$ のの表層硬さは SWOSC-V に比べてHV40 程度高 く，ほぼオイルテンパー線での引張強さの増加に相当して いた。窒化ばねの表層硬さは HV900 以上に達しており SP のみに比べて大幅に上昇していたが，表面からの梁さが $0.05 \mathrm{~mm}$ 程度以上の内部硬さは窒化による軟化のため $\mathrm{SP} の$ みの場合より低くなっていた。

\section{3 残留応力分布}

Fig. 10 に残留応力分布の測定結果を示す。窒化のままで もかなり大きな圧縮残留応力が表面に付与されるが, 内部 に入るにつれその值は急激に低下していた。

窒化後にショットピーニングを施すと, 窒化のままのも のと比較して最表面の圧縮残留応力值は若干低下するが, 圧縮残留応力の最大值はほとんど変わらず，その位置は表 面功深さ $0.05 \mathrm{~mm}$ 程度に移っていた。

また今回のショットピーニング条件では，SPのみの場合 に比ベて窒化後ショットピーニングを施した窒化ばねの表 層部の圧縮残留応力値は大きかった。

\section{4. 考 察 \\ 4.1 疵なしばねの疲労強度 \\ 疲労寿命は主に表層部の硬さや圧縮残留応力に依存する ことが知られている。}

Fig. 5 に示すように SWOSC-V に比べて供試鋼 A の SP の みのばねの疲労強度が向上したのは，扔もに表層の硬さが 高く疲労の第 1 ステージである初期き裂が発生しにくいた めと考兄られる。また，咥化ば衫の疲労強度が大幅に向上 したのは表層の硬さの大幅な増加に加えて, 疲労の第 2 ス テージであるき裂の進展を抑制する圧縮残留応力も增加し たためと考えられる。

\section{2 疵入りばねの疲労寿命}

表面疪が存在する場合，疪先端における硬さが低く，ま た圧縮残留応力が高い方が，疪からの疲労き裂の進展が抑 制され疲労寿命が長くなると考えられる。

供試鋼 A の疵先端部の硬さ分布測定結果を Fig. 11 に示す が，SPのみ及び窒化ばねともに揤のない場合とほぼ同様の 分布であり，疪深さ $0.05 \mathrm{~mm}$ 以上の痱先端の硬さは窒化ば ねの方が SPのみのばねより低い。また，疵先端部の圧縮残 留応力も窒化ばねの方が高いと考元られる（Fig. 10）。これ らのことより, Fig. 6 に示したようにSPのみに比べて窒化

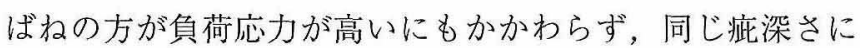
対して同程度の疲労寿命になったものと考えられる。

また，SPのみ及び窒化ばねともに疵深さが $0.05 \mathrm{~mm}$ 程度 以下では疲労強度に影響を及ぼさなかったのは，今回のシ ヨットピーニング条件ではいずれも圧縮残留応力が表面か 


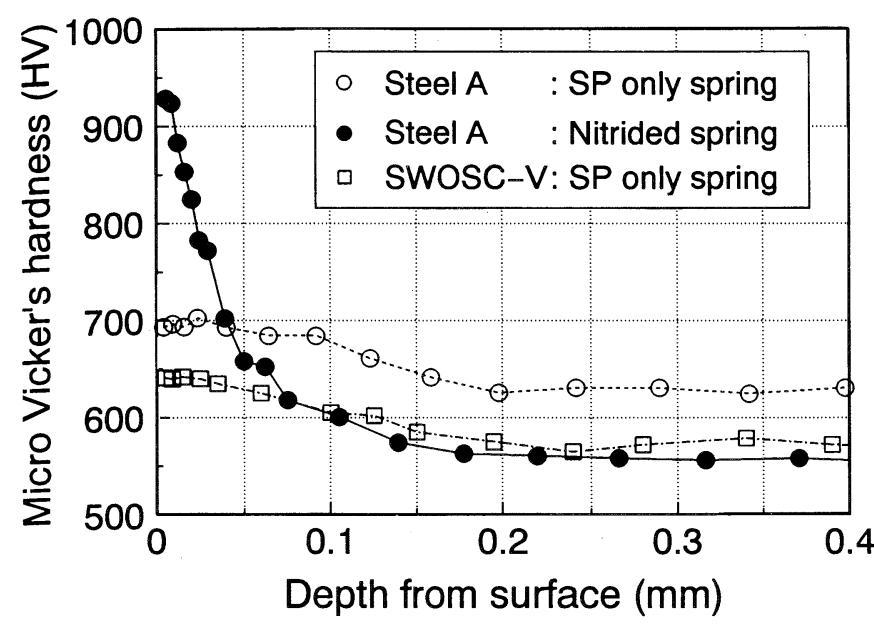

Fig. 9 Hardness distribution of shot-peened springs

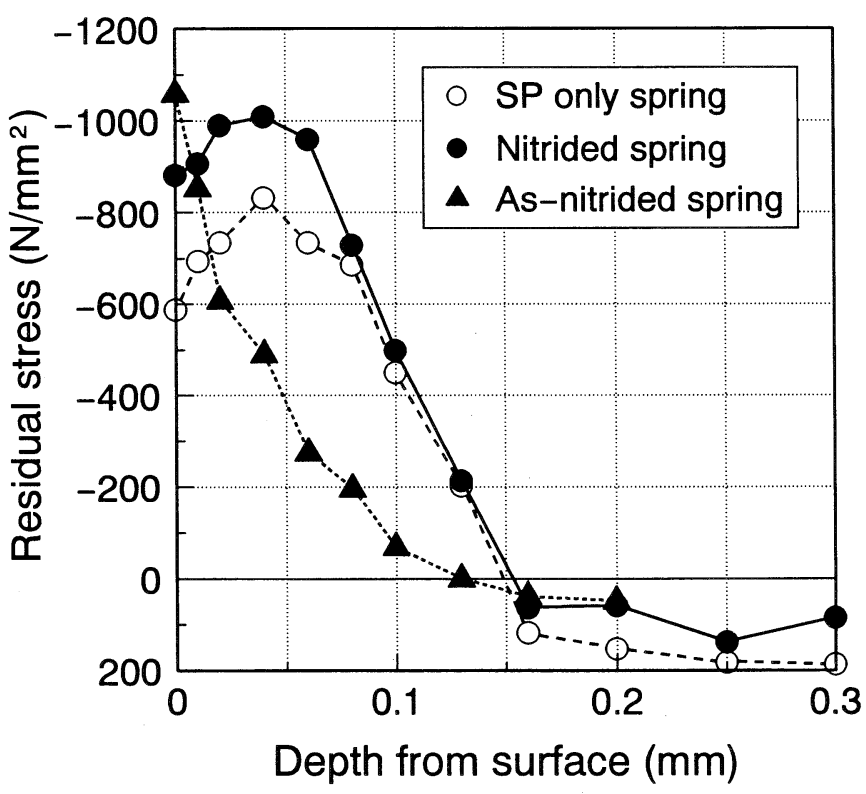

Fig. 10 Residual stress distribution of springs of steel A

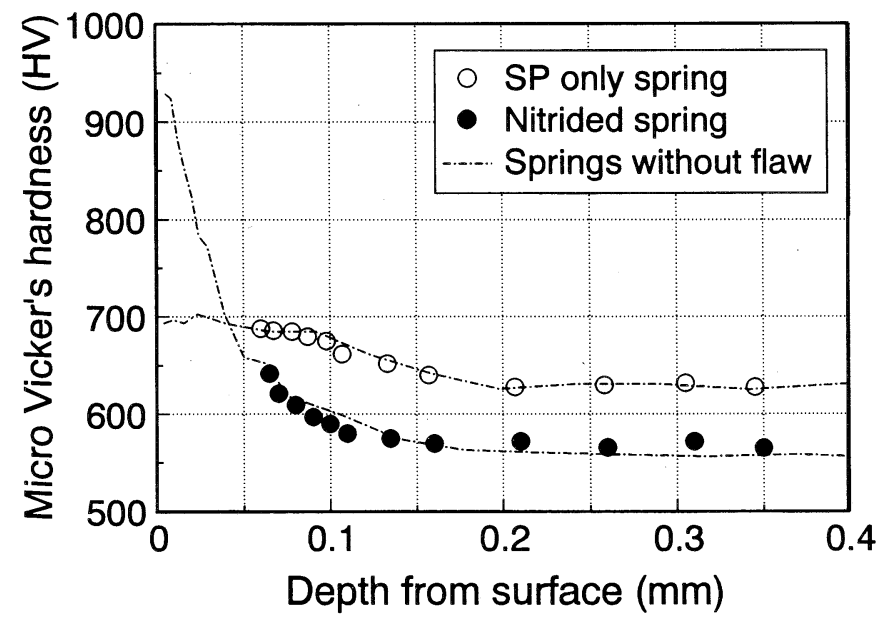

Fig. 11 Hardness distribution from surface flaw tip to inside

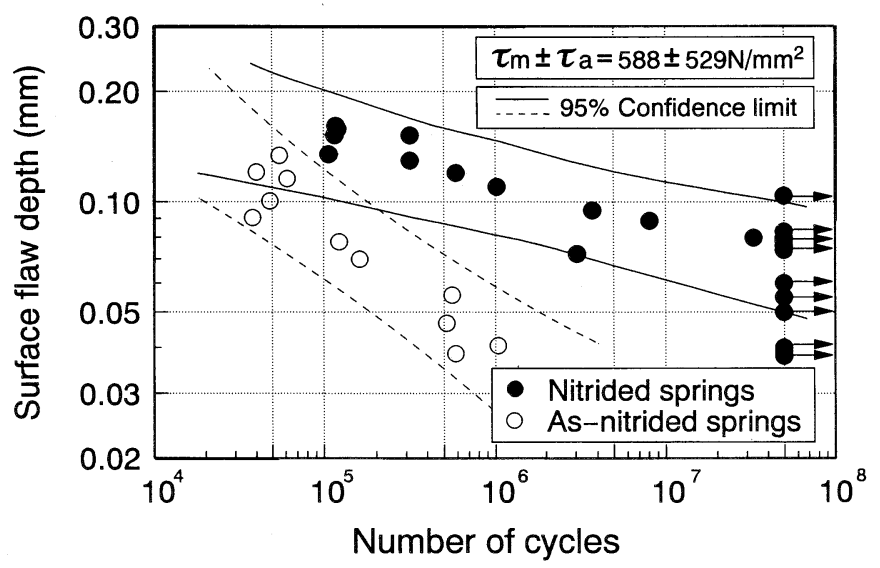

Fig. 12 Relationship between flaw depth at failure initiation poit and fatigue life of nitired and as-nitrided springs

ら $0.05 \mathrm{~mm}$ 付近で最大になっておりり,これが有効に作用し たものと考えられる。

このことを確認するために，表面から内部にかけて圧縮 残留応力が連続的に低下している窒化のままのばね（As nitrided Spring）を用いて疵深さと疲労寿命の関係を調査 した。その結果を Fig. 12 に示すが, 窒化後ショットピーニ ングを施した窒化ばねに比べて窒化のままのばねは疲労寿 命が短くなっている。

Fig. 13 に負荷応力に残留応力を加算した合成応力分布を 示すが，窒化ばねの方が表層部の合成応力が低く，表面か ら約 $0.15 \mathrm{~mm}$ で窒化のままのばねと同程度になっている。 この合成応力が疲労寿命に影響すると考えられ，Fig. 12 に 示したように疪深さ $0.15 \mathrm{~mm}$ 程度では窒化ばねと窒化のま まのばねの疲労寿命はほぼ同程度のであるのに対し，それ 以下の疵深さでは窒化ばねの方が疪先端付近の圧縮残留応 力が高く，したがって合成応力が低いため疲労寿命が長く なったものと考えられる。

\section{5. まと め}

人工疪（縦疪）を有した高強度弁ばね及び窒化ばねの疲 労試験を行い疲労寿命に掠よぼす表面疪の影響を調查した 結果，以下のことがわかった。

（1）両ばねとも疲労寿命は疵深さが深くなるにつれて低下 した。

（2）しかし，疪深さが $0.05 \mathrm{~mm}$ 程度以下では疲労強度の低 下が認められなかった。

この理由としては，ショットピーニングまたは窒化と ショットピーニングの組み合わせにより導入される表層 部の大きな圧縮残留応力が有効に作用したためと考えら れる。

（3）これらのことより，表面疪はできる限り浅くすること が当然必要であるが，疲労寿命に対して表面疪の影響を 小さくするにはとくに表層部の圧縮残留応力を高めるこ とが重要である。 


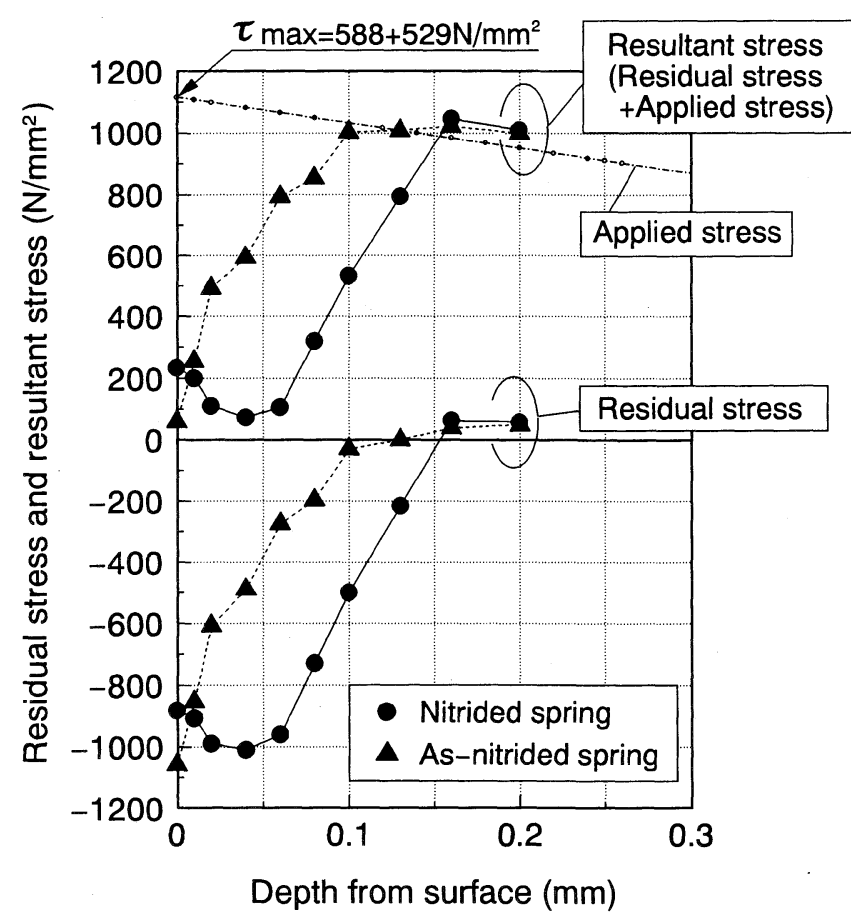

Fig. 13 Distrbution of residual stress and resultant stress

\section{参考文献}

1) M. Abe, T. Taniguchi, T. Kuriki, K. Saitoh, N. Takamura, "Development of a high strength valve spring", SAE Technical Paper Series, No. 890220, 1989.

2）萩原好敏, 伊藤幸生, 小兽根敏夫, 山田勝彦, 林 博昭, 小野田光芳，ばね論文集，No.35，(1990), 13.

3）草刚亘，青木利憲，ばね技術研究会，秋季講演会 (1990) 23.

4) R. H. Gassner, Metal Progress, March (1978), 59. 